\title{
The crisis of bourgeois democracy: the fate of an experiment in the age of nationalism, populism, and neo-liberalism
}

\section{Ronald Grigor Suny}

In the middle of the day on Friday, January 19, 2007, on a main street in Istanbul, in front of his office, Hrant Dink, the courageous editor of the Armenian and Turkish bilingual newspaper Agos, was murdered by a seventeen-year-old man whom he had never met. Shot three times in the nape of the neck, he lay face down on the sidewalk, blood pooling beneath him. His killer fled, brandishing his pistol and shouting, "I have killed an Armenian!" Dink was killed not for any deed or personal grudge, but for who he was and for his words-words that were thought by nationalist Turks and right-wing opponents to be a threat to the Turkish state and to "Turkishness." He was fifty-two years old, a man of enormous energy and passion, someone who embraced those who met him, enveloping them both physically and with his charm and charisma. The circles of his admirers extended far beyond the small, beleaguered community of Turkish Armenians: in the hours after his killing, thousands gathered in Istanbul's central square in the Taksim district, chanting, "We are all Armenians! We are all Hrant Dink!" For those who loved him or were moved by his words, it was impossible to believe he was dead.

Whatever the immediate motives of the young assassin from Trabzon to stop his pen, Dink's death triggered a kind of political earthquake in Turkey. The country was shaken and has never been the same since his death. The tens of thousands who marched through the streets in his memory gained courage

Ronald Grigor Suny, History Department, University of Michigan, 48109-1003, Ann Arbor, Michigan, United States, rgsuny@umich.edu.

Author's Note: This article was originally given as the The Hrant Dink Memorial Lecture at Boğaziçi University on January 20, 2017, to commemorate the tenth anniversary of Hrant Dink's murder. It has been revised and expanded thanks to a generous faculty grant from the Weiser Center for Europe and Eurasia (WCEE) at the University of Michigan. The author is grateful to Geoff Eley, Isebil Gruhn, John Huber, Stathis Kalyvas, Ryan McCullough, Murat Özyüksel, David Priestland, Ivan Sablin, Kim Lane Scheppele, Lewis Siegelbaum, Anoush Tamar Suni, Sevan Suni, Yuri Zhukov, and Erik Jan Zürcher for their comments on earlier drafts, which helped to improve the final piece. 
and realized that there were more dreaming of a better Turkey than they had imagined. In death, Dink gave strength to hundreds of thousands of progressive Turks, Kurds, and Armenians. He had been well aware that he was extraordinarily vulnerable in the corrosive political atmosphere gathering in Turkey, an atmosphere enflamed by state prosecutions of dissident voices and nationalist media. Like the novelist Elif Şafak and the Nobel Prize winner Orhan Pamuk, both of whom had raised the issue of the genocidal deportations and massacres of hundreds of thousands of Armenians in the final decade of the Ottoman Empire, so Dink had been brought before Turkish courts and accused under the infamous Article 301 for "insulting Turkishness." And like the others, he had not been jailed but instead given a suspended sentence, a gesture signaling that the Turkish state was at that time still wavering between adopting the legal norms of Europe and turning its back on the invitation to join the European Union.

Then Prime Minister Recep Tayyip Erdoğan and other state officials condemned the murder, and the culprit-Ogün Samast—was quickly apprehended. But even so, statements from the authorities cast some of the blame on those outside Turkey, such as France, who had brought forth parliamentary resolutions to officially recognize the events of 1915 as a genocide. For eleven years, Dink had edited Agos, a small circulation newspaper, and though it had few subscribers at the time, it resounded like a bell through a quiet night. In an interview with the Committee to Protect Journalists in February 2006, Dink remarked, "The prosecutions are not a surprise for me. They want to teach me a lesson because I am Armenian. They try to keep me quiet." His response when asked who "they" were was the same that would be given by many in the Turkish opposition: "the deep state in Turkey," referring to the derin devlet, the dark forces within the military and the government, as well as nationalist elements, to which at that time even the mildly Islamist Erdoğan government had to defer. ${ }^{1}$

Speaking at Boğaziçi University in 2017 to mark the tenth anniversary of Hrant Dink's murder, I began by noting that in English there are two words used to mark a past event: one is "commemorate," the other "celebrate." That occasion was undoubtedly a commemoration, for a terrible act of murder, a sacrifice of a life, had occurred ten years earlier. But for those gathered in the university hall, I suggested, it should also be a celebration, a celebration of that life, what it meant, and what it has since come to mean. Hrant Dink has become something more than even he imagined himself to be in life, and we ought to celebrate that. I was privileged to know him and to witness his

1 Robert Mahoney, "Bad Blood in Turkey," Dangerous Assignments (Spring/Summer 2006), 27. https://cpj.org/Briefings/2006/DA_spring_06/DA_spring_06.pdf. 
all-encompassing integrity. His sincerity and courage, simplicity and inner power, were evident from our first meeting in Istanbul in the office of the Armenian Patriarch. To those who knew him better, more intimately, he was, of course, a man, a human being, a fallible being with a whole collection of flaws and fears alongside all those indelible qualities of generosity and courage that mark the best of us. He was also a hero, a special kind of human being that today is needed more than ever. A sincere democrat, he believed that democracy was supremely valuable. With true democracy, he thought, a structure could be built and a path laid out that would make possible the solution to the myriad of problems and conflicts that exist in any society. The talk at Boğaziçi and the article here that has emerged from it concern a subject that troubled Hrant and should trouble us as well: the fragility of democracy and the ever present need for the struggle to preserve, enhance, and indeed recreate it.

In the gloom that prevailed after the election of Donald Trump to the presidency of the richest and most powerful nation in history, a Turkish journalist wryly remarked to an American colleague, "Welcome to my country." That fellow could just as easily have been a Russian or Hungarian or Polish journalist, forecasting as he did the turn away from democratic norms, protections of minorities, freedom of expression, and tolerance of differences and toward greater executive power, popular authoritarianism sanctioned by populist revulsion toward the old ruling elites, the rise of chauvinistic nationalism and fundamentalist religion, and a coarsening of political language. The evident current recession in the progress of democracy-along with one of its most important components, the rule of law-in Europe, the Middle East, South Asia, and now the United States has alarmed many journalists, scholars, and ordinary citizens, and it has reminded historians of another slow slip into dark times that occurred almost a century ago.

Democracy, in my view, is an experiment that might, if we are lucky, celebrate its third century of evolution sometime soon. It has traveled a rocky road since the American and French revolutions of the late eighteenth century, and an even rockier one over the last twenty-five years. Since the disintegration of the Soviet Union in the early 1990s and on through the triumphant optimism that marked the collapse of Communist regimes, many states in Europe and the Middle East have experienced relatively rapid political transitions, first from authoritarianism to democracy and later back again to some form of authoritarianism. Those heady, optimistic days at the turn of the millennium have given way to a shared pessimism about the longevity and stability of democracy and to doubts about the possibility of achieving real, lasting, liberal democracy. A quarter of a century ago, political scientists were investigating "transitions to democracy" and the "building of a market economy." There was talk about returning to the "path of civilization" and about "the end of history." Liberalism 
had triumphed. Today, many of those newly established Western-style liberal societies have been replaced by a whole spectrum of new authoritarian regimes, ranging from the restoration (in national garb) of the old Communist nomenklatura in the countries of Central Asia to populist newcomers in Poland and Hungary. Nationalist and populist leaders have stirred up popular fears of alien migrants and a loss of national traditions and used the fears of ordinary people to undermine democratic institutions. Bright spots have no doubt appeared-but the shadows grow longer.

A shift in the progress toward democracy occurred sometime in the mid2000s, and many states that had experienced partial democratization-among them, notably, Russia and Turkey-turned away from true representative government, protection of minorities, and constitutional restraints on executive power. Freedom House reports that 2015 was the tenth year in a row "of decline in global freedom": "The number of countries showing a decline in freedom for the year-72-was the largest since the 10-year slide began. Just 43 countries made gains. Over the past 10 years, 105 countries have seen a net decline, and only 61 have experienced a net improvement." ${ }^{2}$ According to the Democracy Index compiled by The Economist Intelligence Unit in the United Kingdom-an index that measures the state of democracy in 167 countriesin 2016 there were only 19 fully democratic countries (11.4 percent), 57 flawed democracies ( 34.1 percent), 40 hybrid regimes ( 24 percent), and 51 authoritarian regimes ( 30.5 percent). Norway scored highest as the most democratic country in the world, with Sweden a close second, and in fact the five Scandinavian countries were all in the top ten. North Korea scored the lowest. The United States landed at number 21, near the top of flawed democracies; Turkey at number 97, a hybrid regime; and Russia at 134, downgraded from hybrid to authoritarian and ranking well below Georgia, Armenia, and Burkina Faso. ${ }^{3}$

Democracies appear to do worse in societies like Russia, and increasingly the United States, where unfettered capitalism reigns and/or where the

2 Freedom House, "New Report, Freedom in the World 2016: Anxious Dictators, Wavering Democracies," January 27, 2016. https://freedomhouse.org/article/new-report-freedom-world-2016anxious-dictators-wavering-democracies. According to this report, "[o]f the 195 countries assessed, 86 (44 percent) were rated Free, 59 (30 percent) Partly Free, and 50 (26 percent) Not Free." Furthermore, as the report details, "[t]he United States retained its top ratings for political rights and civil liberties but was affected by the cumulative impact over recent years of certain deficiencies in the electoral system, the influence of private money in election campaigns and the legislative process, legislative gridlock, the Obama administration's failure to fulfill promises of enhanced government openness, and fresh evidence of instances of racial discrimination in the criminal justice system."

3 The Economist Intelligence Unit, "Democracy Index 2016: Revenge of the Deplorables." http://felipesahagun.es/wp-content/uploads/2017/01/Democracy-Index-2016.pdf. 
wealthy and the politically powerful work together to enrich themselves and neglect the public good. Democracies function best when effective institutions, impersonal relationships, a prevailing sense of the common good, and the rule of law control and limit personal ambition, corruption, nepotism, and patronclient relationships. Authoritarian systems, on the other hand, thrive on and produce systemic corruption characterized by nepotism and favors from patrons to clients that circumvent the law. Democracies require an educated, informed electorate that can discriminate among the claims made by politicians and the media. In the absence of respect for truthfulness, evidence, and careful argumentation, demagogues prosper. Salesmanship trumps expertise.

Among the states most immediately affected by the recession of democracy are Russia, Turkey, Hungary, Poland, Egypt, Israel, India, the former Soviet republics of Central Asia, and Armenia. In many of these countries, leaders and elites have chosen to amplify executive power to the detriment of legislatures and an independent judiciary. In others, they have promoted nativist and nationalist exclusion of minorities and migrants. Demagogic politicians, such as Donald Trump, exploit the economic distress of working people and their evident rejection of what, for them, were the empty promises of globalized capitalism. In Turkey, President Recip Tayyip Erdoğan moved from democratizing reforms limiting the power of the military and initiating a peace process with the Kurds to an all-out assault on academic freedom, suppression of mass media, accusing opposition politicians of supporting terrorism, and reigniting the war against the Kurds. Understanding how fear works as a political emotion, ambitious politicians are prepared to appeal to the uncertainties of the population, whether these be prompted by terrorism or refugees or economic distress. They exploit people's anxiety; that is, their fear without any clear reason to be fearful and their trepidation about an unknown, anticipated future. Simple, stark messages become the language of politics; exaggeration and outright lies replace reasoned discourse; slogans triumph over careful argument. Populist language deploys anti-elitist and anti-intellectual rhetoric, creating a suspicion of experts and even of science. Leaders deliberately divide society into friends and foes, usually in hypocritical appeals for national unity.

This mélange of causes and responses has, in many countries, fed calls for strengthening the state and having recourse to repression. Right-wing, anti-immigrant movements have affected even consolidated democracies like Denmark, Holland, France, and Germany, among others. The victory of Donald Trump in the 2016 United States presidential election appears to have involved many of the same ingredients: alienation of dispossessed classes, fear of foreigners (the Muslim ban, "build the wall"), attacks on journalism ("the most dishonest people," "enemies of the people") and science, and populist appeals 
("drain the swamp," "America First"). This global erosion of democracy and the rise of popular demands for stronger executive power appear to be transnational, even global, rather than culturally or regionally specific.

How are we to explain this shift away from more liberal democracy to more populist, nationalist, and authoritarian regimes (which often maintain democratic forms and proclaim that they are democracies)? I begin with both a history and a definition of what I understand to be the contemporary form of democracy, what might be called "actually existing democracy" or-the term I prefer-"bourgeois democracy," with the latter concept emphasizing the increased role of property and personal and corporate wealth as a factor undermining democratic choices. I explore how the discourses of politics and the language, practices, and images of leaders have managed to exploit the failures of democratic governments to deal with the colossal problems of income inequality, political polarization, the sense of disenfranchisement on the part of lower- and middle-class people, the fear of cultural loss posed by migration, the perceived threat from radical Islam, and, more fundamentally, the rapidity of change inherent in capitalist modernity.

My provisional hypothesis is that in order for democracies to work best-as in Scandinavia-they must be combined with some form of state welfare and protections for the most vulnerable, a degree of social equality and access to impartial justice, and either a relative homogeneity of population or serious efforts to tolerate, include, and even promote diversity. The shredding of social safety nets that has taken place with globalization has left more and more people exposed to the vagaries of neo-liberal capitalism. Growing social and economic inequality and the increased role of big money in politics has ledthrough lobbies, campaign contributions, influence through the media, and so-called "think tanks" - to the effective capture of the state by big money, a process that seriously threatens meaningful popular participation and democratic choice. Many voters make choices with only limited or distorted information. The people are not stupid: they are ignorant, or, more accurately, they are made ignorant. Fearing the future and foreigners, they turn to more conservative, nationalist, and radical right alternatives to liberal and social democratic parties, as is evident in Western Europe and now the United States.

In liberal modernization theory, the social transformation from village to city, agriculture to industry, and illiteracy to an educated population was supposed to lead toward a Western-style democracy and free market economy. But the particular capitalist modernity that has emerged over the last quarter of a century following the collapse of state socialist modernity has left many people behind. Economic developments have made many people increasingly redundant, superfluous, and unable to cope with de-industrialization. Cultural transformations-such as the increased role of women and the visibility and 
empowerment of minorities, as well as the expanding secularization of lifehave aroused fear in many that their accustomed way of life and beliefs are under threat. In any era, whenever those who had previously been marginalized or subordinated were granted greater opportunity and social mobility, those who had once been privileged because of their ethnicity, "race," job security, or gender experienced equality as oppression. The comfort of traditional values, the conventional family, and religion were undermined, and opportunistic leaders promised restoration of what had been lost. The insecurities that unpredictability aroused drove people to seek easy solutions: strong, confident leaders and a haven, a safe harbor, in a more isolated national family.

Placing the blame on ordinary people has all too often served as an easy explanation for why democratic transitions have failed: it has, for instance, been asserted that Russians like authoritarian leaders or that Turks are blighted by the heritage of Islam. My own investigations, along with those of many political scientists, focus primarily on the actions and ambitions of political elites: the collapse of democracy begins from the top. Democracy requires democrats, and if political elites opt for authoritarian or corrupt paths to power, ordinary people are often left defenseless. ${ }^{4}$ Not only do these political entrepreneurs seek power and a comfortable life at the top, but they also aim to stay at the top. Elites are self-perpetuating, and therefore well poised to thwart democratic transformations. While social, political, economic, and international factors have certainly contributed to the effectiveness of populist appeals, the motivations, actions, and popular successes of leaders like Vladimir Putin, Recip Tayyip Erdoğan, Viktor Orbán, Donald Trump, and others are fundamental to a comprehension of the current anti-democratic moment. Social, economic, and cultural changes have facilitated the erosive work of national populists with authoritarian tendencies. Those changes are associated with the instabilities produced by free-wheeling capitalism, technological changes, the rising rapidity of communication, and the increased movement of money and people-what has been encompassed under the anodyne label "globalization" - and they have made working people vulnerable and insecure, ready targets for demagogues and celebrity politicians. A fatal combination, then, of large-scale processes and self-styled spokesmen for the common man and woman has produced a lethal threat to democracy.

Democracy has had a difficult and troubled history, and not a very long one at that. Two hundred years ago, around 1817, the very word "democracy" connoted for many a pernicious form of government, something akin to mob

4 For an excellent analysis of the erosion of democracy in post-Soviet Russia that locates the principal cause in elite ambitions, see Vladimir Gel'man, Authoritarian Russia: Analyzing Post-Soviet Regime Changes (Pittsburgh: University of Pittsburgh Press, 2015), where the author argues that "[p]ost-Soviet politicians consciously and consistently 'poisoned' political institutions for the sake of maximizing their own power and restraining (if not eliminating) their rivals" (25). 
rule that philosophers as far back as Plato had warned political elites to avoid. In the liberal imagination of the early nineteenth century, class rule was preferable to mass rule. Men-at the time it was almost always men-of property and wealth, who were thought also to have cornered the market on intelligence and judgment, were the ones who should govern the uneducated peasants, laborers, and women. The first parliamentary governments and constitutional monarchies, and even the United States in its first century and a half, were not really fully democratic: they were limited liberal regimes representing primarily people of property. Only a century or more of struggle by, first, the middle classes, and along with them urban workers, and later women, managed to expand the franchise and give the vote to broader swaths of the population. Only then did truly democratic governments emerge.

So, what do we understand democracy to be? For political scientists, democracy is a system of representative government that is elected freely-that is, without coercion-by the entire adult population without restriction and with equal access to the ballot box. It is a government based on popular sovereignty that is exercised through free and regular elections. Governments can be replaced by future elections, so those who lose know they will not suffer imprisonment or death and can indeed be elected to govern in future elections. A situation like that experienced in Turkey in 2014-2015, where the governing party's maximal goals were thwarted by the surprising electoral success of the pro-Kurdish Peoples' Democratic Party (Halklarin Demokratik Partisi, HDP) and the government subsequently worked to cripple that party, eventually arresting its principal leaders, is profoundly anti-democratic. Moreover, a democratic government is not simply the rule of the majority, but also rule by law, with guarantees of certain freedoms like freedom of speech and assembly, and with protection of the rights of minorities.

Democracy - that is, rule by the people, which at a minimum meant one person, one vote-was only achieved in the twentieth century when women and ethnic and racial minorities were given the right to vote. One can reasonably argue that the United States only began to become fully democratic in the 1960s, with the civil rights legislation that empowered African Americans. But even then, that achievement was not only limited by social and economic difficulties, but has ever since been deliberately and steadily eroded by the efforts of conservative whites and the Republican Party to prevent certain segments of the population from voting.

By the twentieth century, democracy had become the form of government in the major and most advanced capitalist countries. ${ }^{5}$ Liberals, especially during

5 Göran Therborn, "The Rule of Capital and the Rise of Democracy," New Left Review I, no. 103 (May-June 1977), 3. 
the Cold War, argued that democracy required capitalism and a strong middle class, and that capitalism worked best with democracy. The fact that a powerful minority-what Marxists referred to as "the bourgeoisie"-held disproportionate political power in democracies through their control of the levers of economic power and the media became an acceptable norm in liberal thought, a paradox questioned by socialists and communists. Marxists generally saw capitalism and democracy as incompatible, or at least in serious tension. The Swedish political theorist Göran Therborn labeled the modern form of actually existing democracy "bourgeois democracy" because "the state apparatus has a bourgeois class composition and the state power operates in such a way as to maintain and promote capitalist relations of production and the class character of the state apparatus." ${ }^{, 6}$ Liberal or bourgeois democracies are characterized by an intimacy between economic power and political power, which at the best of times might be checked by the cultural power of the media and intellectuals. A constant and growing danger arose, however, when economic elites infiltrated and influenced the autonomy of the means of cultural productionthe press, publishing, mass media, and the educational system, most importantly universities.

Another curiosity of the history of bourgeois democracy has been that it emerged first in Europe as a result of the mobilization of the unrepresented, those without the vote-laborers and, later, women. Socialist parties were at the forefront of the so-called "forging of democracy." 7 Although this history has largely been forgotten, for more than a century between 1860 and 1960 socialist parties were the most consistent and persistent advocates of democratization. The working class everywhere fought not only for higher wages and shorter hours but-along with anarchists, feminists, and environmentalists-for political democracy, either as an end in itself or "as an integral part of the struggle for socialism." 8 Democracy-what now was becoming "mass democracy" rather than "class democracy" - grew alongside industrialization and capitalism, the urbanization of peasants, and the rise in mass education. But, as Therborn points out, the working class was nowhere strong enough to establish democracy on its own: instead, splits in the ruling elites and defeats in foreign wars aided the extension of the franchise to mass constituencies. The propertied classes made concessions to working people

6 Ibid., 4.

7 For the relationship between socialist movements and the spread of democracy, see Geoff Eley, Forging Democracy: The History of the Left in Europe, 1850-2000 (New York: Oxford University Press, 2002); and his "What Produces Democracy? Revolutionary Crises, Popular Politics, and Democratic Gains in Twentieth-Century Europe," in History and Revolution: Refuting Revisionism, ed. Mike Haynes and Jim Wolfreys (London and New York: Verso, 2007), 172-201, 244-252 [notes].

8 Therborn, "The Rule of Capital," 34. 
when confronted with their movements and in order to prevent a more radical socialist revolution. ${ }^{9}$ At the same time, the political left was notoriously divided between those more moderate liberal and socialist forces that accommodated capitalism and believed that democracy did not require the elimination of private ownership of the means of production, and those more radical forces that favored a revolutionary transformation and the abolition of capitalist relations of production. With the Bolshevik Revolution and the formation of Communist parties and later states, democracy in Russia and other countries ruled by Leninist parties became a casualty of the authoritarian tendencies associated with Vladimir Lenin and Joseph Stalin. Moreover, socialism became a casualty of its identification with Stalinism and the chasm between Social Democrats and Communists, which opened the way for fascism.

As the caste-like system of aristocratic privilege based on birth broke down and opportunity arose for the entrepreneurial, capitalism and democracy began to look as if they were inclusive, integrating ever more different constituencies into the pays légal. Indeed, historically the struggle for democracy was a series of battles, often losing ones, against exclusion and for inclusion: inclusion of all men regardless of class; inclusion of women; inclusion of minorities and peoples of other ethnicities and religions; and inclusion of those with different points of views, opinions, and ideologies. More ambiguously, capitalism was at the same time both inclusive and exclusive. As Therborn said:

Even if capitalist markets do have an inclusive aspect, open to exchange with anyone, regardless of colour, sex or politics [...] as long as it is profitable, capitalism as a whole is predominantly and inherently a system of social exclusion, dividing people by property and excluding the non-profitable. A system of this kind is, of course, incapable of allowing the capabilities of all humankind to be realized. And currently that system looks well fortified, even though new critical currents are hitting against it - most unexpectedly and impressively, the upsurge in support of the [Bernie] Sanders campaign in the US. ${ }^{10}$

9 In Therborn's words: "Capitalist relations of production tend to create an internally competing, peacefully disunited ruling class. [...] In the absence of a single centre, some kind of elective, deliberative and representative political machinery became necessary. Therefore, propertied republics or parliamentary monarchies developed at an early stage in the formation of capitalist states" (31). He goes on to conclude as follows: "Democracy developed neither out of the positive tendencies of capitalism, nor as a historical accident, but out of the contradictions of capitalism. Bourgeois democracy has been viable at all only because of the elasticity and expansive capacity of capitalism, which were grossly underestimated by classical liberals and Marxists alike" (35).

10 Göran Therborn, “An Age of Progress?” New Left Review 99 (May-June 2016), 31. 
In the last third of the nineteenth century and the first third of the twentieth century, capitalism left unchecked and unrestrained, as Thomas Piketty has shown, led to economic polarization, a widening gap between the very wealthy and the rest of us. ${ }^{11}$ That pattern, which has again emerged in the last quarter century, compromises and indeed undermines equality as well as the access to education, information, and the political process that democracy requires.

Democracy took on a generally positive meaning in the late nineteenth century and through the twentieth century. With the rise of nation-states and the consolidation of popular sovereignty, democracy became the sign of modernity, championed by the most developed countries of the West, though challenged on the right by fascism and on the left by Communism. Fascism, in particular, was a reactionary response to the discontents produced by capitalist modernity. It was a radical, racist populism. Although not all populisms are fascist, fascism was the extreme version of a particularly nationalist and imperialist strain of populism. With the defeat of fascism in World War II, liberal democracy and social democracy retrospectively became the ideals for which the war had been fought. The end of the war inaugurated a social democratic moment in both Europe and the United States. Unrestrained capitalism was blamed both for the depression and for the rise of fascism. A degree of deference toward the privileged and propertied, rather than radical opposition as in populism, went along with elite concessions affecting the welfare, social security, and improvement of the working classes. The answer, even in the programs of moderate and conservative parties, was to use state power to curtail the most malign effects of unfettered market dynamics. The German Christian Democrats declared that " $[t]$ he new structure of the German economy must start from the realization that the period of uncurtailed rule by private capitalism is over," while the French Catholic Mouvement Républicain Populaire proclaimed that it supported a "revolution" aimed at forging a state "liberated from the power of those who possess wealth."

After World War II, Europe enjoyed an unprecedented period of democratic evolution and social and economic development. Because of the massive destruction of private wealth that occurred during the Great Depression and World War II, and owing to the programs of the Social Democrats throughout Europe, aided by the Marshall Plan, a period of economic growth, eventual prosperity, and greater economic and social equality lasted for the next thirty years. Democracy and the welfare state were the visible signs of progress, civilization, and modernity. A different kind of capitalism was promoted, one that was "tempered and limited by the power of the democratic state." 13

11 Thomas Piketty, Capital in the Twenty-First Century (Cambridge, MA: Harvard University Press, 2014).

12 Quoted in Sheri Berman, "The Lost Left," Journal of Democracy 27, no. 4 (October 2016), 70.

13 Ibid., 71. 
Classical liberals like Friedrich Hayek warned that this state intervention represented a "road to serfdom," but in fact over these three decades Europe grew faster economically than it ever had before (or has since). More people were educated than ever before, infant mortality fell, and people lived longer. Inequality was lessened and social mobility enhanced. Workers had the muscle to influence policy, for better or worse, through their unions and socialist and Communist parties. A democratic logic of governing became dominant, one based on negotiation, compromise, give and take, and respect (even if grudgingly given) for your opponents. Even more, a social democratic logic-the understanding that we are all in this together-ameliorated individualism with a sense of the collective and the common good.

The new international financial order established after World War II with the Bretton Woods system, the International Monetary Fund, the World Bank, and eventually, in 1995, the World Trade Organization was founded at a moment of Keynesian economic consensus, when the imperfections of the market were understood to require vigorous adjustment by governments and the collective action of global organizations in order to restore and develop weaker economies. Intelligent and progressive economists and politicians were determined to learn from the past and avoid another catastrophe, preserve capitalism, and liberal democracy. What has been called the "European Project"-the Common Market and later the European Union-was in fact a concerted effort to avoid the disasters of the first half of the twentieth century, which had led to the death of tens of millions in two world wars, and construct a more unified Europe based on the principles of humanism, liberalism, multicultural tolerance, regulated capitalism, and democracy. After the defeat of fascism and occupation by the victors, West Germany, Italy, and Austria created thriving democracies; in the mid-1970s, Spain and Portugal moved from authoritarianism to democracy; and from 1989 on, the former Communist states transitioned, albeit unevenly, in a generally democratic direction. The end of the Cold War encouraged Latin American states to move against their military dictatorships and create more democratic governments. The United States-which had backed dictatorships in the western hemisphere, Asia, and Africa as long as they were anti-Communist-became more willing to promote more democratic regimes. One might also add that the erosion of Kemalism fostered by Erdoğan's Justice and Development Party (Adalet ve Kalkınma Partisi, AKP), as well as the eruption of the Arab Spring, represented important efforts, regrettably shortlived, to democratize states in the Middle East. Democracy as a political desideratum had become hegemonic.

But this period of bourgeois democracy and social welfare working together eventually floundered on the shoals of an economic slowdown, the so-called "crisis of stagflation." Capitalist globalization raised the living standards of parts 
of the non-European world, relegating many of the more privileged working and middle classes of the first world redundant and resentful as they were threatened by competitors in less developed countries. The Keynesian consensus that had reigned among economic thinkers since World War II, between roughly 1945 and 1975, gave way between roughly 1975 and 2008, to the neo-liberal synthesis. The Keynesian period had been characterized by a commitment to capitalism, private property, profit-making, and market allocation, but within constraints set down by democratic political processes. The state was still an important factor in restraining the worst excesses of laissez-faire and promoting a degree of social equality, primarily through the taxation system and welfare entitlements. This changed in the time of Margaret Thatcher and Ronald Reagan, and was promoted by Bill Clinton through his free trade policies and deregulation of the financial system. Over time, the sense of mission on the part of policymakers and economists changed radically as neo-liberal monetarist ideas became ever more dominant. ${ }^{14}$ Instead of policies aimed at job creation, the International Monetary Fund promoted capital market liberalization, privatization, reduction of state intervention, and the end of protectionism-all so-called "structural adjustment programs." The disintegration of Soviet-style state "socialism" at the precise moment of the triumph of Thatcher, Reagan, Milton Friedman, and the "Chicago Boys" eliminated the principal obstacle to a global capitalism as well as any experiments toward "third-way" alternatives. Even earlier, first in Augusto Pinochet's Chile and later in Argentina and Bolivia, neo-liberal reforms were implemented with a heavy dose of political repression.

With the fall of the Berlin Wall in 1989, the self-styled "socialist" world was de-socialized: shock therapy dismantled the statist economy, impoverished the majority of the people, and enriched those few who used political connections to become the new capitalists. The Berlin Wall was breached, borders opened, people could now travel, drugs and AIDS flowed into the post-Soviet space, and a globalized circulation of educated and mobile women became a new source of sex trafficking. In some countries, the market system was accompanied by democratic reforms, but in others a new kind of authoritarian capitalism or state capitalism became the norm. With the end of the Cold War, the whole world became integrated into a single accelerating global capitalism, with the United States as the sole economic and military superpower on a global scale. The socialist alternative, and even Keynesianism, were discredited. The world became one-dimensional, with possibilities outside of capitalism and the magic of the market unimaginable.

14 This point is made by Joseph E. Stiglitz, Globalization and its Discontents (London and New York: W.W. Norton, 2002), 11-14. 
Global capitalism had both united the world into a single giant market and divided it into two worlds that, as Tariq Ali writes, "face[d] each other across a divide that first appeared in the eighteenth and became institutionalized in the nineteenth century":

Much of the twentieth century witnessed several attempts to transcend this division through a process of revolutions, wars of national liberation and a combination of both, but in the end capitalism proved to be more cunning and resilient. Its triumph has left the first of these worlds as the main repository of wealth and the principal wielder of uncontrolled military power. ${ }^{15}$

The neo-liberal regime fostered by the United States and the major international financial and economic institutions usually denigrated the role of the state, instead touting the market as the provider of all relevant information and the most efficient means to prosperity. Government, as Ronald Reagan said, was not the solution, it was the problem. While the neo-liberals talked about rolling back the state, their actual policies shrewdly, and even cynically, used the state so as to reward the rich and punish the poor-through tax breaks for the rich, elimination of the welfare system, and an assault on organized labor. ${ }^{16}$

Effective politicians understand that language matters. Arguably the most far-reaching effect of the "Reagan Revolution," along with its attacks on organized labor and the expansion of military spending, was that president's extraordinary success in shifting the dominant discourse of American politics from New Deal liberalism to a significantly more anti-government, marketoriented conservatism-or what is now called "neo-liberalism." Reagan legitimized being conservative, a position that had been marginal and largely negative in the heyday of liberal reformism that stretched from the presidency of Franklin Delano Roosevelt through that of Lyndon Johnson. If, in the period up through the mid-1970s, democracy and capitalism had been accompanied by greater social and economic equality, after the 1970s bourgeois democracy and neo-liberal capitalism were marked by greater economic inequality, stagnating social mobility, and a sense of loss of social standing. Between 1988 and 2011, the richest 10 percent of the world's population appropriated 46 percent of global income growth. While what we used to call "actually existing socialism"-that is, the regimes of the Soviet Blocessentially achieved a rough social and economic equality but crushed

15 Tariq Ali, The Clash of Fundamentalisms: Crusaders, Jihads, and Modernity (London and New York: Verso, 2002), 3.

16 This hypocrisy is nicely caught in the title of Dean Brown's book, The Conservative Nanny State: How the Wealthy Use the State to Get Rich and Stay Richer (Washington, DC: Center for Economic and Policy Research, 2006). 
democracy, bourgeois democracy has maintained democratic procedures but crushed the essence of democracy by permitting, as Bernie Sanders has called it, "obscene levels of inequality."17

Capitalist globalization lifted up parts of the world's population even as it depressed others. The unevenness of these developments has had profound social and cultural effects-not least of which has been the anxieties produced by the flows of labor and migrants. In a talk given immediately following the election of Donald Trump, the historian of fascism Geoff Eley succinctly summarized this particular conjuncture.

My own view [...] is that the creation of a borderless world (in the neoliberal sense), the collapse of state sovereignties in a huge expanse of territory from West Africa through to Afghanistan, and the unstoppable continuance of the crisis of global migrancy (these are obviously shorthands) are all generating the materials for virulent popular anxieties about boundaries and borders inside the societies of the advanced capitalist countries, thereby generating dynamics that can only become more and more destabilizing as rivalries over resources grow more and more unpredictable and extreme (hence the structuring determination exercised by climate change). In the end, it's these anxieties about borders and boundaries and about difference that drive a great deal of the right-wing nationalist vehemence that we've been witnessing in the Trump campaign and the analogous politics in Europe. ${ }^{18}$

Around 2008 there was another seismic shift in public and professional thinking about domestic and global economics, a shift that followed hard upon the housing and banking collapse of that year. While there was plenty of blame for the causes of the crisis to go around, a British economist summed up the essential factor:

It is no exaggeration to say that the crisis stems from the biggest regulatory failure in modern history. Many politicians and commentators are stressing that "we are all to blame" - the international economy, bankers, investors, ratings agencies, consumers. But this simply diverts attention from those whose job it was to regulate: the regulators and the political authorities who sanctioned them. ${ }^{19}$

17 I thank Lewis Siegelbaum for this point.

18 Geoff Eley, "Is Trump a Fascist?" Learn Speak Act: Liberal Arts in the Moment. https://sites.Isa.umich. edu/learn-speak-act/2017/04/12/is-trump-a-fascist/.

19 Robert Wade, “Financial Regime Change?" New Left Review 53 (September-October 2008), 12. 
Debt rose astronomically as the housing bubble burst; the credit crunch froze the banking system and economies began a rapid meltdown; the efficient markets idea was briefly discredited and the necessary role of government was widely, and often reluctantly, accepted. As we entered a new period in the history of global capitalism, it appeared at first, very briefly, that we were headed toward a new Keynesianism. When in doubt and desperation, turn to the government! But in the end neo-liberal economic orthodoxies proved too strong, and the people in power provided no viable alternatives to business as usual. ${ }^{20}$ No bankers went to jail: there was too much self-interest among politicians, particularly in the United States, to continue to reward those who had brought on the crisis. Austerity policies became the new norm in much of Europe over the next decade, even to the point of threatening the unity of the European Union.

After the economic bust hit Europe, the right became the major beneficiary of the downturn. In Hungary in 2010, Viktor Orbán won 53 percent of the vote and two-thirds of the seats in parliament, thus empowering his party, Fidesz, to make constitutional changes. The first areas to suffer were the independence of the courts and freedom of the press. Kim Lane Schepple calls this the building of a "Frankenstate" - a combination of all the worst features of government. ${ }^{21}$ In Turkey, Recep Tayyip Erdoğan's AKP won its third parliamentary election in 2011, a moment that increasingly looks like the turning point away from democracy and toward personal authoritarianism. In Russia in 2012, Vladimir Putin won another election as president and, despite a short-lived series of protests, remained extraordinarily popular, with an approval rating above 80 percent due to the simple fact that people could see no alternative. In Poland in 2015, Jarosław Kaczyński's party came to power with a commitment to move Poland away from multiculturalism and liberalism. The 2016 victory of those favoring Brexit served as a powerful signal that a new illiberal orthodoxy was emerging. Internationalism and democracy, it was proclaimed, were not necessary for economic growth-just look at Singapore and China. Liberalism, it was claimed, was dividing society and undermining national traditions-what was needed was a new holistic approach that would preserve national uniqueness. With the left shattered after the so-called "fall of Communism," a new and perverse alternative to Western democracy and its

20 David Priestland, "Are we at a Piketty tipping point for the left? Unfortunately, history suggests not," The Guardian, May 7, 2014. https://www.theguardian.com/commentisfree/2014/may/07/thomaspicketty-capital-in-the-21st-century. For a prescient argument about the rise of merchants and the limits of capitalism, see Priestland's book Merchant, Soldier, Sage: A New History of Power (London: Alan Lane, 2012).

21 Kim Lane Schepple, "The Rule of Law and the Frankenstate: Why Government Checklists Do Not Work," Governance 26, no. 4 (October 2013): 559-562. 
Enlightenment values appeared: radical, fundamentalist religious political movements, the most virulent of which was militant Islamism.

A great opportunity was lost when a dedicated liberal, Barack Obama, became president of the United States. In the heady early days when people clamored for change, a man known for the power of his oratory failed to articulate a new language of politics. Between his victory speech in Chicago in November 2008 and his first inaugural address a few months later, rather than promote an aggressive liberal agency and enunciate a clear and forceful liberal discourse, the moderate, guarded, deferential, and humane Obama instead sought to work and compromise with intransigent Republicans in the United States Congress. As income inequality continued to grow, the enormous successes of the first two years of Obama's presidency-the Affordable Care Act ("Obamacare") and the stimulus that jumpstarted a moribund economygave millions of Americans health insurance, thereby executing a major downward distribution of wealth. But the Republican opposition, whose major interest appeared to be tax "relief" to the wealthiest Americans, relentlessly opposed this moderate and flawed program, convincing roughly half of the population that the Affordable Care Act was not actually in their interests. In doing this, the Republicans adopted a new style of politics that would have been familiar to Lenin: no compromise with the enemy and war rather than negotiation. In its dogged determination to thwart all of Obama's initiatives, the Republicans in Congress brought the legislative process to a grinding halt. While the right-wing conglomerate of individuals and interest groups known as the Tea Party played on the racist and anti-elitist sentiments of those who felt marginalized by the liberals and their globalizing and multiculturalist policies, the left provided no effective alternatives to the anxieties felt by a fearful and insecure population. Conservatives and nationalists raised the specter of threats from immigrants, particularly Muslims. As Jacques Rupnik put it, "[i]n the context of a major migration crisis, it is culture war-rather than the economy - that has weakened liberalism and facilitated the slide toward illiberal democracy." 22

Only late in his second term did Obama get his mojo back and stake out a more defined and determined liberalism. But this proved to be a case of too little, too late, and was quickly overwhelmed by the triumph of the Trumpists, who came to Washington, DC armed with reckless rhetoric and prepared to dismantle as many liberal achievements as they could so long as they held the three branches of the federal government and the majority of the state houses and legislatures. Instead of draining the swamp, as Trump had promised, the alligators had taken control.

22 Jacques Rupnik, "Surging Illiberalism in the East," Journal of Democracy 27, no. 4 (October 2016), 81. 
In Europe, a growing number of voters have come to see the European Union as an elite project that supports globalization and the free movement of refugees. Both the Greek crisis and Brexit were signs of failures on the part of the EU, which in many minds is identified with the harmful effects of liberalism and democracy. In the United States, a significant proportion of the voting public sees both the Democratic and the Republican elites as advocates of globalization, which is framed as free trade, open borders, and illegal immigration, combined with the threat of Islamic terrorism. A growing distrust of the liberal elites from below targeted Hillary Clinton, and the discontent with free trade policies and the liberal left's neglect of ordinary working people combined in a toxic environment that, in November 2016, upset the political expectations of most pundits and pollsters. The billionaire demagogue Donald Trump shamelessly portrayed himself as the champion of working people, and was elected president. He then set about forming the most conservative government in American history, made up of billionaires, radical right-wing ideologues, and retired generals. When one contemplates the trajectory from the New Deal of Franklin Delano Roosevelt through the New Society of Lyndon Johnson and the brief hopeful period of the Obama presidency to the triumph of Trump, one senses not just disenchantment with liberalism, but a genuine degeneration of politics and political discourse more generally.

In the first months of 2017, the new Republican president-who during his campaign had even threatened to arrest and try his Democratic opponentbegan to dismantle Obama's programs without first putting viable alternatives in place. His chief ideological advisor, Steve Bannon, had proudly announced that he was a Leninist (though what he understood about Lenin remains obscure), proclaiming that "Lenin wanted to destroy the state and that's my goal too. I want to bring everything crashing down and destroy all of today's establishment." 23 American politics-along with those of Russia, Turkey, Hungary, India, and others-shifted to a new logic: winner take all; no compromise with your opponents. A logic of warfare rather than democratic negotiation and compromise took over.

There are many reasons why it is rational in 2017 to be worried about democracy's political future. Across established, consolidated democracies in North America, Russia, and Western Europe, research has shown that citizens "have not only grown more critical of their political leaders. Rather, they have also become more cynical about the value of democracy as a political system, less hopeful that anything they do might influence public policy, and more

23 Victor Sebestyen, "Bannon Says He is a Leninist: That Could Explain the White House's New Tactics," The Guardian, February 6, 2017. https://www.theguardian.com/commentisfree/2017/feb/06/leninwhite-house-steve-bannon. 
willing to express support for authoritarian alternatives." ${ }^{24}$ The fall in faith in democracy and the rise in support for military rule or authoritarian leadership has most dramatically risen among the wealthy. ${ }^{25}$ To many working- and middle-class Americans, liberalism (not to mention socialism) are associated with a redistribution of wealth and services to the lower classes and undeserving minorities, and those who are better off resist such transfers with all their might.

It was no longer Communism haunting Europe, but active illiberal parties that "see society as riven by a single cleavage between the vast majority and some 'establishment'; they encourage polarization and reject compromise; and their belief that they represent the greater and best part of 'the people' makes them prone to intolerance of minorities, impatient with institutional legalities, and inclined toward raw majoritarianism. ${ }^{26}$ Some of the illiberal parties are openly anti-democratic as well, such as France's National Front, Greece's Golden Dawn, Hungary's Jobbik (the Movement for a Better Hungary), Belgium's Vlaams Belang (Flemish Interest), along with a number of small "leftist" parties that, like the Russian Communist Party, are remnants of the old Communist parties and that in fact look more brown than red. Adding to the mix are the most important nativist parties, which thrive in the most affluent states of Europe: the Freedom Party of Austria (Freibeitliche Partei Österreichs, FPÖ); the Dutch Party for Freedom (Partij voor de Vrijheid, PVV); the Danish People's Party (Dansk Folkeparti, DF); Norway's Progress Party (Fremskrittspartiet, FrP); the Sweden Democrats (Sverigedemokraterna, SD); the Finns Party (Perussuomalaiset, PS; formerly known as the True Finns); the Swiss People's Party (Schweizerische Volkspartei, SVP); the UK Independence Party (UKIP); and the Alternative for Germany (Alternative für Deutschland, AfD). More moderate than the outwardly anti-democratic and nativist parties are the centrist, ostensibly democratic, but notably illiberal populist movements: Silvio Berlusconi's Forza Italia in Italy, Viktor Orbán's Fidesz in Hungary, Robert Fico's Direction - Social Democracy (Smer - Sociálna Demokracia, Smer-SD) in Slovakia, Jarosław Kaczyński’s Law and Justice (Prawo i Sprawiedliwość, PiS) party in Poland, and Recip Tayyip Erdoğan's aforementioned AKP. On the other side, left-wing populist parties like Podemos in Spain and Syriza in Greece are anti-capitalist but not antidemocratic. Distinctions can of course be made between all these parties, but they do share many common features. The danger comes if they win enough votes. At that point, their anti-liberalism and hostility toward governing elites may become

24 Roberto Stean Foa and Yascha Mounk, "The Democratic Disconnect," Journal of Democracy 27, no. 3 (July 2016), 7.

25 Ibid., 13.

26 Takis S. Pappas, "Distinguishing Liberal Democracy's Challengers," Journal of Democracy 27, no. 4 (October 2016), 31. 
much stronger than their belief in representative democracy. ${ }^{27}$ Leon Trotsky once characterized Stalinism as "the syphilis of socialism"-we might think of populism as the syphilis of democracy.

Democracy has been more a means than an end for the populist strongmen of Europe, and now the United States, to consolidate their power. Erdoğan's initial victories promised broader participation in politics to Muslims who had been marginalized under the Kemalist system. Permission to wear headscarves in state offices and universities served as a symbolic opening for the religiously observant and for women. In the first six years of AKP rule, reforms brought the Turkish state closer to the norms of the EU, and yet Europe remained steadfast in its refusal to admit Turkey, thereby effectively undermining the more democratic forces within the country. Without recognizing the massacres and deportations of Ottoman Armenians and Assyrians in 1915-1916 as a genocide, the Erdoğan government nevertheless allowed more open public discussion, even in the mass media, of an alternate narrative of the collapse of the empire and the founding of the Republic of Turkey, one that explicitly destabilized the hitherto hegemonic Kemalist reading of the past.

At the same time, as prime minister Erdoğan pushed through constitutional changes that made the presidency a directly elected position, following which he not only was elected president and increased his powers through the force of his own personality and dominance of the AKP, but also pushed for a referendum on a new constitution that would transform Turkey from a parliamentary to a presidential system. Turkey's constitutional court was crippled when the president was granted greater power to appoint judges, and the power of the military was curtailed through fabricated court cases and charges of conspiracy. Erdoğan suffered a setback when a Kurdish political party, the Peoples' Democratic Party (Halklarin Demokratik Partisi, HDP), won enough votes and seats in June 2015 parliamentary elections to slow his momentum toward centralizing his power. In response, he called for new elections. A fresh outbreak of violence in southeastern Anatolia and a vicious military campaign against Kurdish resistance helped to sway opinion away from the opposition and give Erdoğan a slim victory in the general election of November 2015. After a clumsy and bloody attempted

27 Ibid., 32. Pappas concludes his article as follows: "Populism, which is the flipside and negation of political liberalism, is by far the most menacing challenger. As empirical research shows, it thrives where political institutions - especially the rule of law and safeguards for minority rights - are weak and where polarization and majoritarian tendencies are strong. In such environments, populist parties can be expected to win power via the ballot box and even to win reelection. Populism is so threatening because it has a contagious quality - the appearance and rise of a populist party will predictably push a country's other parties in a populist direction-and because populism can lead to the decay of liberal institutions and the consolidation of illiberal polities. The ongoing success of populism in places such as Greece, Hungary, and, more recently, Poland provides a warning for all Europe" (35). 
coup d'état on July 15, 2016, parliament approved emergency powers that removed immunity from HDP deputies. Leading members of the party were arrested, along with journalists, writers, and other critics of the government. Thousands of people were imprisoned and tens of thousands dismissed from government posts, accused of being allied with the religious movement centered around the exiled cleric Fethullah Gülen, who was blamed for organizing the coup attempt. ${ }^{28}$ Academic freedom was drastically reduced as universities were brought under tighter state control. Fear was pervasive, the future unpredictable.

Americans experienced similar disorientation after Donald Trump's improbable election. Searching for answers, many blamed Vladimir Putin and purported Russian hacking of the Democratic National Committee for Hillary Clinton's defeat. Russia, it was said, once again posed a threat to American democracy. A more sober analysis might have considered that the greater threat lay closer to home, from populists and nativists. A particularly noxious form of politics, the current wave of populism uses democracy to appeal to nationalist, nativist, and illiberal voters and deploys flamboyant rhetoric with little regard for careful argumentation, or even for the truth. During Trump's campaign, one adviser gave him advice that he probably did not actually need: "Never apologize [...] Facts are white noise [...] [E]motions rule." ${ }^{29}$ The triumphant Trumpists believe that we live in a world in which facts do not matter and lies can be effective: "alternative facts" propagated through mass and social media and subsequently denied if necessary. They understand, as we must, that lies are potent weapons against progress, science, and democracy. Along with a logic of war, they operate from what I will call a "business logic" - what sells is worthwhile, what is popular is valuable. It is the sales that matter, not the product. This is a logic that is distinct and dangerous when it replaces the different logics of serious science, scholarship, and democratic politics. ${ }^{30}$ Think

28 Kim Lane Scheppele situates the Turkish case within the wider setting of threats to constitutional democracy in "The End of the End of History," Toronto Law Review (forthcoming): 1-38; see especially 26-29.

29 Steven Erlanger and Kimiko de Freytas-Tamura, "Godfather of Brexit Takes Aim at the British Establishment," The New York Times, January 20, 2017. https://www.nytimes.com/2017/01/20/world/ europe/arron-banks-brexit-britain.html.

30 This is an old struggle. Consider the campaign of the tobacco industry in the United States, which sixty years ago formed a counter-truth to the scientific conclusion that cigarette smoking causes lung cancer. For half a century they managed to confuse people and prevent legislation and efforts to curb smoking. Tobacco executives perjured themselves before Congress. In 2000, the current vice president, Mike Pence, took money from those companies and declared proudly that, "despite the hysteria from the political class and the media, smoking doesn't kill." Ultimately, after tens of thousands of people needlessly died and untold profits flowed into its coffers, Big Tobacco lost that battle-but there were others: the sugar industry, in its defense of high fructose corn syrup, attacked scientists who showed the dangers of these products, and the oil company Exxon took up the cudgel against the scientific consensus that climate change is created by people and is a danger to the future of life, human and otherwise, on this planet. 
about the effect that commerce and merchandising had on broadcast, cable, and social media in the 2016 presidential campaign, giving billions of dollars of free air time to Trump, who raised ratings and revenues-not to mention the money made by hucksters dishing out "fake news."

A functioning democracy requires a different logic from the logics of warfare or of business. Democracy involves not only negotiation and compromise, accepting defeat in the anticipation that you might win later, but it also rests on the belief that argumentation is effective and that reasoned discussion and logical persuasion can change minds. We have lost something extraordinarily precious when fake news and conspiracy theories take over the public sphere, or when your opponent is threatened with "lock her up."

Business logic is nakedly personified in the larger-than-life figure of Donald Trump. It would be wrong to conclude that Trump is not intelligent: he is very intelligent in a very particular way, which has made him extraordinarily successful. He is cunning, he is calculating, he is all about what serves him and his family and his enterprises best, at any cost to others that is sustainable and within the law-or that he can get away with. He is not stupid, but he is ignorantignorant of history particularly. Like Putin, Erdoğan, Orbán, and others, he seems to understand instinctually how subversive an accurate knowledge of history can be. As a distinguished scholar of Turkey put it: "A society built on secrecy and lies about its past can much more easily be manipulated through secrecy and lies in the present. It is a disease, and a chronic one." 31

The current problem may be Trump and his cronies in the White House, along with their parallels in other failing democracies, but the fundamental problem of capitalist democracy long preceded Trump. He is only the clearest, most naked manifestation of that deeper problem: the overwhelming and growing power of men of greater wealth and property in and over government and the mass media, along with the penetration of business logic into governance and the calculation of profit and individual and corporate gain over any sense of the common good. That logic will be dominant as long as Trump remains president, and in an even more extreme way that it has been over the last thirty or forty years.

If you live long enough and pay enough attention, you learn the hard lesson that political solutions are provisional; always temporary, never permanent.

Climate change, declared Donald Trump, is a Chinese hoax, and confidently went on to appoint the chairman of Exxon to become the next Secretary of State. See Ari Rabin-Havt, "Trump's Outrageous Lies Come Straight from Big Business' Playbook," The Washington Post, December 16, 2016. https://www. washingtonpost.com/posteverything/wp/2016/12/16/trumps-outrageous-lies-come-straight-from-bigbusinessess-playbook/?utm_term=.d515f1e8eefd. Rabin-Havt is also the author of Lies Incorporated: The World of Post-Truth Politics (New York: Anchor Books, 2016).

31 Private email message from Erik Jan Zürcher, February 20, 2017. 
The Trumpists who came to power on January 20, 2017 can quickly undo nearly everything that the eight years of Obama's presidency achieved. But we must believe that all the damage that Trumpism will create can also be undone in time, with sustained effort, good will, and determined resistance. We must not mistake the present for the future.

Two hundred years after movements for democracy first emerged in modern times, the struggle continues. Indeed, at the moment it needs to be intensified. So, what is to be done? This essay-just like the mood among liberals, democrats, progressives, and the left more generally—is at the moment understandably dark and pessimistic. But pessimism does not lead to movement and change. Optimism is required; faith in the power and importance of democratic institutions and the rule of law must be supplemented by civil society activism; positive programs, and even utopian thinking about possible alternatives, is needed. ${ }^{32}$ In an upbeat article in New Left Review, Therborn wrote: "Against, or perhaps, more cautiously, alongside the sombre mood prevailing on the left, including the environmentalist left-of-centre, it can be stated that humankind today is at a historical peak of its possibilities, in the sense of its capability and resources to shape the world, and itself. Never has humankind faced its future with greater mastery of the world."33 Optimism leads to action; pessimism leads to the Right. ${ }^{34}$

The protest against business as usual in the United States produced not only Trump and Trumpism, but their opposites as well: Bernie Sanders and a youth movement that was purposefully Left. A significant number of young people seem to understand that bourgeois democracy is not enough, that a new social democracy is required. A recent Harvard poll found that 47 percent of young adults aged 18 to 29 believe that basic necessities like food and shelter

32 For a discussion of the danger of depending on institutions and the need for civil society to act, see Daron Acemoglu, "Against Trump. America's Institutions Weren't Designed to Resist a Modern Strongman. That Leaves Civil Society," FP, January 18, 2017. http://foreignpolicy.com/2017/01/18/ we-are-the-last-defense-against-trump-institutions/.

33 Therborn, "An Age of Progress?", 27.

34 As David Runciman wrote, "The US is not a failed state. How do we know? Because that's what Trump said it was during the election campaign and he was lying. He portrayed his country as a place of failed institutions and widespread corruption, its inner cities racked with violence and its political class interested only in enriching itself. It would be a big mistake to think that he won because people believed him. Had they believed him they would hardly have voted for him: putting a man like Trump in charge really would spell the end for American democracy, because it would have left him free to do his worst. People voted for him because they didn't believe him. They wanted change but they also had confidence in the basic durability and decency of America's political institutions to protect them from the worst effects of that change. They wanted Trump to shake up a system that they also expected to shield them from the recklessness of a man like Trump." David Runciman, "Is This How Democracy Ends?" The London Review of Books 38, no. 23, December 1, 2016. 5-6. https://www.Irb.co. uk/v38/n23/david-runciman/is-this-how-democracy-ends. 
are a right the government should provide to those unable to afford them; 48 percent think that basic health insurance is a right for all people; and a slight majority of so-called "millennials" think positively about the idea of socialism.

Demagogic populist politicians are likely to succeed in the short run. Their domination of the media allows them to spin positive representations even of failed policies. Free trade and neo-liberal programs may pump the stock market and appear to be helping the economy grow. The damage that such policies will do will be delayed, as we shall see, for instance, with the refusal of the Trumpists to recognize the long-term dangers of climate change. Putin benefited domestically from the annexation of Crimea, but the international and domestic economic and political costs of that move will be felt in Russia and Ukraine for decades to come. Erdoğan reaped the whirlwind when he ended the peace negotiations with the Kurds and turned to violence and suppression, but it remains a mystery how Turkey will subsequently manage to provide a peaceful future together with its tens of millions of Kurdish citizens. When the state is seized by self-aggrandizing or nationalist politicians who promote one group over another, law becomes an instrument that no longer mediates social relations or protects the less advantaged, but is instead used by the few as a tool to favor those in and close to power.

If you take the time to watch the speeches, press conferences, and interviews of Donald Trump, you may be appalled by the level of bombast and selfcongratulation, by the naked display of narcissism, and by the obvious exaggerations and outright falsehoods. But when you turn to comedic commentary on Trump—to Saturday Night Live, Jon Stewart, Stephen Colbert, The Daily Show, or Full Frontal with Samantha Bee-you will not only be relieved by the humorous portrayals of the simultaneously ridiculous and dangerous figure now in the White House, but-hopefully-encouraged by how skillfully satire can expose the fraud and absurdity of both the president and the political culture of the United States. Along with optimism and hope, a sense of humor is a necessary weapon against despair. In the right place at the right time and delivered with the right inflection, comedy can disturb, disrupt, and unsettle what appears normal and acceptable. A deftly drawn cartoon or a parodic song can unnerve those who portray themselves as invulnerable. Erdoğan squealed when he was gored by a German comedian who touched a nerve in the thin-skinned president. "A properly addressed ridicule does not only perform the task of social disinfection," writes literary scholar Serguei Oushakine, "it also has an important organizing function, creating and encouraging

35 The national Reason-Ruper survey revealed that 53 percent of 18- to 29-year-olds view socialism favorably, compared to only a quarter of Americans over 55. A YouGov survey in January 2016 found that 43 percent of those younger than 30 viewed socialism favorably, compared to 32 percent thinking favorably of capitalism. See Emily Ekins and Joy Pullman, "Why So Many Millennials are Socialists," The Federalist, February 15, 2016. http://thefederalist.com/2016/02/15/why-so-manymillennials-are-socialists/. 
a sense of community among its readers and spectators. ${ }^{36}$ Humor, particularly satire, contains a transgressive potential within it. A risk is taken without fully knowing what the effect or response will be. It takes guts to tell a joke, especially one that talks back to power.

But besides jesters, movements need thinkers, organizers, leaders-they need heroes. And one example is the man whom we gathered to commemorate and celebrate in January 2017-Hrant Dink. While he was vitally interested in setting the record straight on the events of 1915, and believed that people and governments must be honest about their history, Dink was most interested in the movement for Turkish democracy. Democracy in Turkey, he believed, would easily settle historical matters and educate people about the tragedies that had befallen Armenians and others in the past. Dink's lack of fanaticism on the issue of the Armenian Genocide made him suspect to many of his compatriots abroad, although his outspokenness in the face of official sanction gave him a heroic aura. The year before he was killed, the Norwegians awarded him the Bjørnson Prize for protection of freedom of expression.

The paradox of Dink's death is that he was killed in the name of a particularly narrow notion of patriotism, even as he was himself a fervent Turkish patriot. His vision of his native country was of a modern democratic, tolerant state, the eastern edge of Europe, in which his own people, the Armenians, could live together with Turks, Kurds, Jews, Greeks, and all the other peoples who had co-existed, however uneasily, in the cosmopolitan empire out of which the Republic of Turkey had emerged. Dink was an active participant in Turkey's vital civil society, key members of which have taken up the question of the Armenian Genocide as an opening wedge to investigate the blank spots in Turkey's past. He participated in international meetings that included Armenian and Turkish scholars exploring the causes and consequences of the policies of the Young Turk government during World War I. The year before his murder, he spoke publicly at a Turkish academic conference on this theme at Istanbul's Bilgi University, a breakthrough meeting that clearly frightened those nationalists who wished to bury the inconvenient past. What he could not tolerate was any denial of the shared history of those peoples, a history that involved mass killing of Armenians and Assyrians, the expulsion of Greeks, and the continued repression of Kurds. Coming to terms with history is the necessary first step toward building a new democratic society. Inclusion, not exclusion and isolation, give us the strength to imagine alternatives to the darkness that appears to be gathering around us. For us older people, maybe our eyes are failing, so we turn to the younger among us who, inspired by a hero like Hrant Dink, can envision and struggle for a more

36 Sergeui Alex. Oushakine, "'Red Laughter': Refined Gestures of Soviet Jesters," Social Research 79, no. 1 (Spring 2012), 197. 
humane, inclusive, and tolerant democratic future. Consider the wise words of comedian Irwin Corey-the absent-minded "professor" and self-proclaimed "World's Foremost Authority" - who warned us, "If we don't change direction soon, we'll end up where we're going."

\section{References}

Acemoglu, Daron. "Against Trump. America's Institutions Weren't Designed to Resist a Modern Strongman. That Leaves Civil Society." FP. January 18, 2017. http://foreignpolicy.com/2017/01/18/ we-are-the-last-defense-against-trump-institutions/.

Ali, Tariq. The Clash of Fundamentalisms: Crusaders, Jihads, and Modernity. London and New York: Verso, 2002.

Berman, Sheri. “The Lost Left.” Journal of Democracy 27, no. 4 (October 2016): 69-76.

Brown, Dean. The Conservative Nanny State: How the Wealthy Use the State to Get Rich and Stay Richer. Washington, DC: Center for Economic and Policy Research, 2006.

Ekins, Emily and Joy Pullman. "Why So Many Millennials are Socialists." The Federalist. February 15, 2016. http://thefederalist.com/2016/02/15/why-so-many-millennials-are-socialists/.

Eley, Geoff. Forging Democracy: The History of the Left in Europe, 1850-2000. New York: Oxford University Press, 2002.

. "What Produces Democracy? Revolutionary Crises, Popular Politics, and Democratic Gains in Twentieth-Century Europe." In History and Revolution: Refuting Revisionism. Edited by Mike Haynes, and Jim Wolfreys. London and New York: Verso, 2007. 172-201, 244-252 [notes].

__. "Is Trump a Fascist?" Learn Speak Act: Liberal Arts in the Moment. November 21, 2016. https:// sites.Isa.umich.edu/learn-speak-act/2017/04/12/is-trump-a-fascist/.

Erlanger, Steven and Kimiko de Freytas-Tamura. "Godfather of Brexit Takes Aim at the British Establishment." The New York Times. January 2120, 2017. https://www.nytimes.com/2017/01/20/world/ europe/arron-banks-brexit-britain.html.

Foa, Roberto Stean and Yascha Mounk. "The Democratic Disconnect." Journal of Democracy 27, no. 3 (July 2016): 5-17.

Freedom House. "New Report, Freedom in the World 2016: Anxious Dictators, Wavering Democracies." January 27, 2016. https://freedomhouse.org/article/new-report-freedom-world-2016-anxiousdictators-wavering-democracies.

Gel'man, Vladimir. Authoritarian Russia: Analyzing Post-Soviet Regime Changes. Pittsburgh: University of Pittsburgh Press, 2015.

Mahoney, Robert. "Bad Blood in Turkey." Dangerous Assignments (Spring/Summer 2006): 26-28. https:// cpj.org/Briefings/2006/DA_spring_06/DA_spring_06.pdf.

Oushakine, Sergeui Alex. "Red Laughter': Refined Gestures of Soviet Jesters." Social Research 79, no. 1 (Spring 2012): 189-216.

Pappas, Takis S. "Distinguishing Liberal Democracy's Challengers." Journal of Democracy 27, no. 4 (October 2016): 22-36.

Piketty, Thomas. Capital in the Twenty-First Century. Cambridge, MA: Harvard University Press, 2014.

Priestland, David. Merchant, Soldier, Sage: A New History of Power. London: Alan Lane, 2012.

_ . "Are we at a Piketty tipping point for the left? Unfortunately, history suggests not." The Guardian. May 7, 2014. https://www.theguardian.com/commentisfree/2014/may/07/thomas-picketty-capitalin-the-21st-century.

Rabin-Havt, Ari. Lies Incorporated: The World of Post-Truth Politics. New York: Anchor Books, 2016.

_. "Trump's Outrageous Lies Come Straight from Big Business' Playbook." The Washington Post. December 16, 2016. https://www.washingtonpost.com/posteverything/wp/2016/12/16/trumpsoutrageous-lies-come-straight-from-big-businessess-playbook/?utm_term=.d515f1e8eefd.

Runciman, David. "Is This How Democracy Ends?" The London Review of Books 38, no. 23 (December 1, 2016). https://www.Irb.co.uk/v38/n23/david-runciman/is-this-how-democracy-ends.

Rupnik, Jacques. "Surging Illiberalism in the East." Journal of Democracy 27, no. 4 (October 2016): 77-87. 
Schepple, Kim Lane. "The Rule of Law and the Frankenstate: Why Government Checklists Do Not Work." Governance 26, no. 4 (October 2013): 559-562.

"The End of the End of History." Toronto Law Review (forthcoming): 1-38.

Sebestyen, Victor "Bannon Says He is a Leninist: That Could Explain the White House's New Tactics." The Guardian. February 6, 2017. https://www.theguardian.com/commentisfree/2017/feb/06/lenin-whitehouse-steve-bannon.

Stiglitz, Joseph E. Globalization and its Discontents. London and New York: W.W. Norton, 2002.

The Economist Intelligence Unit. "Democracy Index 2016: Revenge of the Deplorables." http:// felipesahagun.es/wp-content/uploads/2017/01/Democracy-Index-2016.pdf.

Therborn, Göran. "The Rule of Capital and the Rise of Democracy." New Left Review I, no. 103 (May-June 1977): 3-41.

"An Age of Progress?" New Left Review 99 (May-June 2016): 27-37.

Wade, Robert. "Financial Regime Change?" New Left Review 53 (September-October 2008): 5-21. 